\title{
THE DEVELOPMENT OF THE VIRUS CONCEPT AS REFLECTED IN CORPORA OF STUDIES ON INDIVIDUAL PATHOGENS*
}

\section{LESSONS OF THE PLANT VIRUSES-TOBACCO MOSAIC VIRUS}

\author{
by
}

\section{LISE WILKINSON**}

THERE is no dearth of references to virus diseases of man in the writings of antiquity. Although caution is called for, and rash identification of clinical descriptions should be avoided, there are both individual case histories and epidemic situations mentioned in the literature of disparate cultures which suggest the presence of smallpox and rabies before 1000 B.C. ${ }^{1}$ By the time Celsus came to write De medicina, his observations on rabies were not only superior to those of Aristotle; they were also remarkably accurate in many respects. ${ }^{2}$

In contrast, plant disease, whether of viral or other origin, appears to have attracted scant attention until the sixteenth century. The De contagione et contagionis morbis et eonum curatione, published in Venice in 1546 by Girolamo Fracastoro, is claimed by historians to be a landmark in the history of bacteriology. ${ }^{3}$ He included a chapter on "The analogy of contagions" in which he wrote: "... there is a certain pest which attacks trees and crops, but harms no sort of animal; again, there is a pest which attacks certain animals but spares trees and crops. In the animal world, one pest will attack man, another cattle, another horses, and so on ...."4 Fracastoro was aware of the transmission of "contagions" by contact, mentioning for example phthisis, pestilent fevers, and smallpox; in one chapter he speculated on the possibility of infections spreading from fruit to fruit, i.e. grape to grape, apple to apple, etc., in a similar way. ${ }^{5}$ The larger fruits understandably lent themselves more easily to observation, and the extent of observation was in some measure determined by the importance of individual crops. Today, Fracastoro's remarks may appear as no

-This work was made possible by a grant from the Wellcome Trust.

* Lise Wilkinson, Cand. Pharm., Mag. Scient., Department of Virology, Royal Postgraduate Medical School, Du Cane Road, London W.12.

${ }^{2}$ B. M. Lersch, Geschichte der Volksseuchen, Berlin, S. Karger, 1896, pp. 1-20.

- Celsus, De medicina, Eng. trans. by W. G. Spencer, London, William Heinemann, 1938, vol. 2 , pp. 111-115.

For an assessment of Fracastoro's contribution, see W. Bulloch, The history of bacteriology, London, Oxford University Press, 1938, pp. 9-12.

- Hieronymi Fracastorii, De contagione et contagionis morbis et eonum curatione, 1546. Translation and notes by Willmer Cave Wright, New York and London, Putnam, 1930, see Book I, chapter 8, p. 39.

'Ibid., chapter 3, p. 9. 


\section{Lise Wilkinson}

more than trivial truth; seen in their sixteenth-century context, they were perspicacious indeed. ${ }^{6}$

Thirty years later, in 1576, there appeared in Antwerp a work of a very different kind. The author was the Dutch botanist variously referred to as Carolus Clusius, or Charles de l'Escluse. ${ }^{7}$ It was a treatise on rare plants, with an appendix concerned with Clusius' own observations on tulips. At this time, the tulip had only recently been introduced into Europe; the first authentic record we owe to the man who was probably responsible for its introduction. He was Ogier Ghislain de Busbecq, ambassador from Ferdinand I of Austria to the court of Sultan Soliman the Magnificent from 1554 to 1562 . Busbecq may have brought tulips back to Vienna as early as $1555 ;^{8}$ by 1575 Clusius had by his own account received considerable numbers of seeds and bulbs from Busbecq, forming a more than adequate collection on which to base his extensive observations. Even at this early stage, Clusius observed colour changes in his specimens, and described and even illustrated (Fig. 1) the characteristic patterns of what has since become recognized as a viral disease, i.e., the so-called "breaking", or tulip mosaic disease. This is the earliest identifiable record of a plant virus disease in the western world, and for two hundred years, until the observations on potato "degeneration" in Britain and on peach yellows in America" in the late eighteenth century, it remained the only one. It was far from being immediately recognized as a morbid condition; on the contrary, although Clusius himself did realize that bulbs producing tulips with colour breaks had less vitality than the selfcoloured ones, ${ }^{10}$ the visual appeal was such that "broken" or variegated varieties remained most desirable for three hundred years, and are currently enjoying a renaissance in commercial bulb catalogues.

Within a short time, tulips with colour breaks found their way not only into botanical volumes, ${ }^{11}$ but also into the work of the great painters of the period. Jan

- These passages are quoted, with other relevant material, in Milestones in microbiology, edited and translated by Thomas D. Brock, London, Prentice-Hall, 1961.

${ }^{7}$ Charles de l'Escluse published his initial observations on tulips as an appendix to Rariorum aliquot stirpium per Hispanias observatarum historia, Antwerp, 1576, and presented further revised data in Rariorum aliquot stirpium, per Pannoniam, Austriam, \& vicinas quasdam provincias observatarum historia, Antwerp, 1583. Extracts from these and other works by l'Escluse, together with biographical details, may be found in F. W. T. Hunger, Charles de l'Escluse, s'Gravenhage, 1927. The author is the same Hunger who wrote on tobacco mosaic virus in 1905 (note 54 below), and who after 1917 concentrated on his interest in the history of botany and eventually became director of the Institute for the History of Medicine and Biology in Leyden. An English translation of the full text of Clusius' observations on tulips may be found in A treatise on tulips by Carolus Clusius of Arras, translated and annotated by W. van Dijk, Haarlem, Joh. Enschede en Zonen, 1951.

${ }^{8}$ See M. B. McKay and M. F. Warner, 'Historical sketch of tulip mosaic or breaking. The oldest known plant virus disease', Natn. hort. Mag., 1933, 12: 179-216, p. 186.

- See F. C. Bawden, Plant viruses and virus diseases, New York, Ronald Press Co., 1964, pp. 18-19.

${ }^{10}$ In one paragraph Clusius described accurately the colour changes resulting from virus infection, and added: "And this also I have observed, that any tulip thus changing its original colour is usually ruined afterwards and wanted only to delight its master's eyes with this variety of colours before dying, as if to bid him a last farewell". (A treatise on tulips by Carolus Clusius of Arras, op. cit. note 7 above, p. 18).

11 Variegated tulips are described by John Gerard in The herball, or general historie of plants, London, 1597, pp. 116-119. All of Gerard's tulip illustrations are identical with some of Clusius', although the accompanying texts differ, and in fact in neither case do they show much relevance to the plants depicted. It was common practice at this time to reproduce expensive woodcuts in various unrelated volumes; several of the tulip illustrations reproduced by Clusius had appeared in earlier 


\section{Lessons of the plant viruses-tobacco mosaic virus}

Brueghel12 invariably included "flamed" or "feathered" tulips in his elaborate flower canvases, and also in the flower garlands which he provided for several of Rubens' Madonnas. ${ }^{13}$ When Rembrandt van Rijn painted his young wife Saskia as "Flora" shortly after their marriage, in 1634, her long loose hair was crowned by an elaborate arrangement of flowers, a large white tulip with characteristic red feathering drooping over her left ear. ${ }^{14}$ At the end of the eighteenth century, one Robert Thornton, lecturer on medical botany at the United Hospitals of Guy and St. Thomas, whose reputation unfortunately in no way improved with the years ${ }^{15}$ produced in London a particularly fine example of botanical illustration featuring a total of seven tulips all showing various distinctive patterns characteristic of viral infection. Thornton made no mention of self-coloured tulips, nor was there any suggestion in his text that the striped varieties were suffering from an anomalous condition, or that the bulbs might be less vigorous than those of non-variegated varieties. Nevertheless, at this time the notion that "breaking" in tulips was the manifestation of some kind of chronic disorder or weakness was certainly considered among botanists; but as to the cause of the disorder, it was more or less agreed that adverse environmental conditions were responsible. The comment by William Hanbury, in 1770, that "All variegations are diseases in a plant and nothing is so proper to bring this about as a defect in nutriment"16 reflects the general attitude in an age when it was common practice to weaken bulbs deliberately by transfer to poor soils in order to encourage the process of "rectification". 17

This is not at all surprising when we consider the state of the theories concerning human infectious disease at this time, and well into the nineteenth century. ${ }^{18}$ But what is perhaps surprising is that although tulip mosaic disease has a far more impressive historical record than any other plant virus disease, the realization that it was a communicable plant disease, let alone a virus disease, came surprisingly late. When it did come, in $1928,{ }^{19}$ it passed largely unnoticed outside the circles of plant pathologists; to most other people at this time, "plant virus" was almost synonymous with tobacco mosaic virus. In the field of plant virus studies, tobacco mosaic virus

volumes by Plantin and by Matthias de l'Obel, and hardly any illustrations used by Gerard in his herball are original (W. T. Stearn, personal communication).

12 Jan Brueghel (1568-1625), the younger son of Pieter Brueghel the elder, painted almost exclusively flower canvases.

${ }^{13}$ A particularly fine example of this famous collaboration may be seen in Munich's Alte Pinakothek.

14 This painting is now in the Hermitage Museum in Leningrad's Winter Palace.

${ }^{16}$ Robert John Thornton was born in 1768. At the age of sixteen he went up to Trinity College, Cambridge, and, preferring medicine to theology, on to Guy's Hospital Medical School, where he later became a lecturer on medical botany. Although we can still admire his magnificent botanical plates in The Temple of Flora, London, 1799, the ambitious scale and quality of his botanical engravings and their accompanying texts became his financial undoing, and he died a ruined man in 1837.

${ }^{16}$ William Hanbury, Complete body of planting and gardening, vol. I, London, 1770, p. 301.

${ }^{17}$ See McKay and Warner, op. cit., note 8 above, p. 201.

18 See for example W. Bulloch, op. cit., note 3 above, pp. 155-168; also E. H. Ackerknecht, 'Anticontagionism between 1821 and 1867', Bull. Hist. Med., 1948, 22: 562-593.

${ }^{10}$ M. B. McKay, 'Narcissus and tulip diseases', Rep. Ore. St. hort. Soc., 1926, 18: 137-150; D. M. Cayley, " "Breaking" in tulips', Ann. appl. Biol., 1928, 15: 529-539; D. M. Cayley, "Breaking" in tulips II', ibid., 1932, 19: 153-172. Although these papers purported to establish tulip mosaic as a viral disease on comparative grounds, the filterability of the virus remained in question. 


\section{Lise Wilkinson}

has always occupied a very special place, and with good reason. It was the first infectious agent found to pass through the pores of so-called bacteria-proof filters, and by its very existence it initiated the concept of the "filterable virus", and also a controversy which was to rage for nearly half a century. This happened quite soon after bacteriology had become established as an academic subject following the pioneer studies of Pasteur and of Koch. Schools of pathology were just beginning to offer courses in bacteriology 20 when, in 1879, a local chapter of the Dutch Agricultural Society became alarmed at the spread of a plant disease which had been worrying the tobacco farmers of Holland for many years. ${ }^{21}$ Samples of diseased leaves were sent to the Director of the Agricultural Experiment Station at Wageningen, Adolf Mayer, ${ }^{22}$ who then embarked on a long and detailed study, the results of which were published in 1885 and $1886 .{ }^{23}$ Mayer first established the transmissibility of the disease by inoculating healthy plants with sap extracts from crushed leaves of diseased specimens which had been passed through filters. He found a reduction in infectivity following repeated passage through double layers of filter paper, a result which could not be confirmed by later researchers. His main contribution is usually considered to be his insistence on the need for research in this area as well as the coining of the name which has ever since been associated with not only this, but also a number of other plant virus diseases producing similar symptoms in a wide range of higher plants: mosaic disease.

However, a closer examination of the early literature on tobacco mosaic disease suggests that possibly Adolf Mayer has received rather less than a fair share of credit for original, constructive thought which led straight to the pioneering experimental work of the two men acclaimed as the originators of the concept of filterable plant viruses, the Russian botanist Ivanovski, ${ }^{24}$ and the ubiquitous Dutch genius of early microbiology, W. M. Beijerinck. ${ }^{25}$ In the papers in which these two men independently established the filterability of the pathogen of tobacco mosaic disease, both referred to Mayer's study. When Ivanovski described his initial observations, ${ }^{26}$ he

\footnotetext{
${ }^{20} \mathrm{E}$. Duclaux, Ferments et maladies, Paris, G. Masson, 1882, is subtitled "cours professé à la Sorbonne en 1879-1880"; in Copenhagen, Carl Julius Salomonsen taught a course in bacteriology in the basement of the Botanical Museum in the 1880s (see E. Schelde-Møller, Thorvald Madsen, Copenhagen, Arnold Busck, 1970, pp. 17-18).

${ }_{21}$ According to Mayer (note 23 below) and Hunger (note 54a below), the disease was first mentioned in the literature by J. H. van Swieten in 1857, when it had been well known to tobacco growers for some time.

"2 Adolf Mayer was born and educated in Germany. After teaching at Heidelberg he went to Wageningen, Holland, as director of the Agricultural Experiment Station from 1876 to 1904, when he returned to Heidelberg.

23 The two papers were 'Over de in Nederland dikwijls voorkommende Mozaikziekte der Tabak', Landb. Tydschrift, 1885, and 'Die Mosaikkrankheit des Tabaks', Landwirtsch. Versuchsstat., 1886, 32: 450-467. An English version of the latter was published by the American Phytopathological Society in 1942 in Phytopathological classics, no. 7.

थ For details of Ivanovski's life and career see H. Lechevalier, 'Dmitri Iosifovich Ivanovski (1864 1920)', Bact. Rev., 1972, 36: 135-145.

${ }^{25}$ For details of Beijerinck's life and work, see L. E. den Dooren de Jong, 'Beijerinck, the man', in Verzamelde Geschriften van M. W. Beijerinck, vol. VI, s'Gravenhage, Martinus Nijhoff, 1940, pp. 3-47 of 'Martinus Willem Beijerinck. His life and his work.'

${ }^{26}$ D. I. Ivanovski, 'On two diseases of tobacco', Sel'. Khoz. Lesov., 1892, 169 (2): 108-121; an English translation of the part of this paper which deals with tobacco mosaic disease, by J. M. Irvine, appears as an appendix to S. S. Hughes, 'The origins and development of the concept of the virus in the late nineteenth century', Ph. D. thesis, London University, 1972.
} 


\section{Lessons of the plant viruses-tobacco mosaic virus}

remarked that his results confirmed Mayer's findings, with the exception of the filtration experiments; obviously Mayer's paper was well known to him. Ivanovski found no loss of infectivity in sap which had been passed through a linen cloth, but remained cloudy and green; Mayer had found that repeated filtration through double layers of filter paper yielded a clear liquid which proved not to be infective. ${ }^{27}$ Mayer was familiar with Koch's postulates and was deliberately searching for a possible bacterial infection; he was also attempting to differentiate between infections by what he called organized and unorganized ferments, and observed: "One should realise that a definite capacity to infect, as has been proved in our case, may be determined either by an unorganised or an organised ferment. It is true that the former would be rather unusual as a cause for a disease, and also that an enzyme should reproduce itself is unheard of. Yet this situation has been taken into consideration in the following". ${ }^{28}$

Ivanovski went one step further. Having negated Mayer's findings by establishing that the infected sap retained its infectivity after passage through a double layer of filter paper, he decided to employ the newly developed method of bacteria-proof filtration. Consequently, he passed the infected sap through a cylinder of very dense, porous clay, a so-called Chamberland filter, developed in the laboratories of Pasteur. The sap retained its infectivity. To Ivanovski, this was proof of his working theory: the disease was the manifestation of effects of a toxin secreted by bacteria. ${ }^{20}$ Ivanovski was able to substantiate his results by quoting Roux; after the very important exposure of diphtheria toxin by Roux and Yersin in 1888, ${ }^{30}$ the action of bacteria through the secretion of toxins seemed a very plausible answer to many problems in pathology. Ivanovski then, logically, began a series of determined efforts to cultivate the unseen bacteria presumably responsible on various media, with no results whatsoever. But he was in no doubt as to the bacterial nature of the agent of tobacco mosaic disease, and concluded his paper with the promise of further, hopefully successful, experiments. However, he did not publish any more studies on the subject until the appearance of Beijerinck's papers on mosaic disease ${ }^{\mathbf{3 1}}$ a few years later induced him to claim priority for the filtration experiments. ${ }^{82}$ In 1903 Ivanovski published his final paper on tobacco mosaic disease which presented the data and conclusions of his doctoral thesis. ${ }^{33} \mathrm{He}$ remained convinced of the bacterial nature of the pathogen, in spite of lack of convincing evidence. He thought he had identified the microbe in microscopical studies (Fig. 2), and considered his attempts to cultivate it on artificial media promising, although he concluded: "All in all the problem of in vitro cultivation of the mosaic disease microbe remains to be solved in future studies". ${ }^{.4}$

Beijerinck's work on the tobacco mosaic pathogen was more directly derived from

${ }^{27}$ A. Mayer, op. cit., note 23 above, p. 22 of the English version in Phytopathological classics.

28 Ibid.

20 Ivanovski, op. cit., note 26 above.

${ }^{20}$ E. Roux and A. Yersin, 'Contribution à l'étude de la diphthérie', Annls Inst. Pasteur, Paris, 1888, 2: 629-661.

"M. W. Beijerinck, 'Ueber ein Contagium vivum fluidum als Ursache der Fleckenkrankheit der Tabaksblätter', Zent. Bakt. ParasitKde, 1899, Abt. II, 5: 27-33.

32 D. I. Ivanovski, 'Ueber die Mosaikkrankheit der Tabakspflanze', ibid,. 250-254.

${ }^{33}$ D. I. Ivanovski, 'Úber die Mosaikkrankheit der Tabakspflanze', $Z$. PfIKrankh., 1903, 13: 1-41.

${ }^{34}$ Ibid., p. 41. 
that of Adolf Mayer. He was at Wageningen between 1876 and 1885, ${ }^{85}$ and became interested in the difficulties Mayer was experiencing in explaining the aetiology of tobacco mosaic disease. In $1887^{36}$ he decided to conduct a few experiments of his own. On the basis of his inconclusive results, Mayer was inclined to believe the disease to be of bacterial origin, rather than caused by an enzyme, although he had considered this possibility. ${ }^{37}$ Having looked in vain for bacteria visible in the microscope, Beijerinck tried every known in vitro method for the cultivation of aerobic as well as anaerobic bacteria. ${ }^{38}$ The results were totally negative. Even at this early stage, Beijerinck appears to have been far less restricted by conventional microbiological thinking than his contemporaries faced with similar problems. He wrote: "These experiments showed with certainty that we were dealing here with a disease which was caused by a contagium not conforming to the concept of contagium fixum in the usual sense". ${ }^{39}$ Several years later, ignorant of Ivanovski's studies, he deliberately set out to filter infected sap through bacteria-proof filters. The filtrate showed no loss of infectivity, although all attempts to isolate either aerobic or anaerobic organisms remained futile. Even when kept for three months the filtrate remained bacteria-free but virulent. To determine whether the pathogen should be regarded as "corpuscular" or as a dissolved substance, Beijerinck examined the capacity of the active principle for diffusion into an agar-gel; as the tobacco mosaic virus did in fact penetrate below the surface layer of the agar, he concluded that he had isolated, for the first time, a pathogen which was not corpuscular, but which was active in a water-soluble form. ${ }^{40}$

Beijerinck also showed, by inoculation and re-inoculation in series, that the pathogen multiplied within the plant. He was then ready to draw his imaginative, and in the context of his time, very remarkable conclusion: "It is then hardly possible any longer to doubt that the contagium must be considered to be a liquid, or perhaps rather a water-soluble substance". ${ }^{11}$ Taking into account the results of his attempts to grow the virus in vitro and in vivo, he then presented, in a few sentences, a boldly imaginative and wholly unprecedented analysis of the possible nature of the agent of tobacco mosaic disease. He wrote: "Although the reproduction or growth of a dissolved particle is not unthinkable, it is difficult to imagine. Molecules equipped with a division mechanism enabling them to reproduce, and the idea of metabolizing molecules which must be a presupposition, seems to me obscure, if not positively unnatural. Hence it might conceivably serve as an explanation that the contagium, in order to reproduce, must be incorporated into the living protoplasm of the cell, into whose reproduction it is, in a manner of speaking, passively drawn. This would at least reduce two riddles to only one, since the incorporation of a virus into the living protoplasm, even if well-documented, cannot by any means

${ }^{2 s}$ Dooren de Jong, op. cit., note 25 above, pp. 14-18; cf. also p. 118.

2 Beijerinck, op. cit., note 31 above, p. 28.

27 Mayer, op. cit., note 27 above.

38 Beijerinck, op. cit., note 36 above.

" Ibid.

40 Ivanovski in 1903 (note 33) sought to rescind Beijerinck's notion of the "fluid" nature of the infective principle by showing that solid particles of ink were also able to penetrate below the surface of an agar plate under similar conditions.

"1 Beijerinck, op. cit., note 31 above, p. 29. 


\section{Lessons of the plant viruses-tobacco mosaic virus}

be considered a thoroughly understandable process." 42

It is tempting to speculate on influences in the early life of Beijerinck, the man, which may have contributed to his extraordinary perspicacity in this new and untried field. Throughout his long life botanical microbiology remained his greatest interest, and he has many important discoveries to his credit. ${ }^{43}$ On a personal level, he was a difficult and solitary man who made few friends; $; 4$ but those few remained friends for life, and one of them in particular doubtless put his stamp on Beijerinck's future career. When Beijerinck graduated from secondary school at the age of eighteen in 1869, he went for financial and practical reasons to study technology at the Delft Polytechnic. The course was not exciting in academic terms, and living conditions were barely adequate $;^{45}$ but the shortcomings were richly compensated for by the formation of a lasting friendship with a fellow student, the subsequently eminent chemist J. H. van't Hoff. ${ }^{46}$ There can be little doubt that their spirited discussions into the small hours and the chemical experiments the two performed together ${ }^{47}$ left a lasting impression on Beijerinck's fertile mind, and enabled him in later life to consider chemical molecules and even their possible role in biological systems in a more realistic way than could most of his fellow biologists and pathologists at the time.

The difference in approach is well illustrated when we compare Beijerinck's conjecture with the interpretations offered by those who found other pathogens to be filterable in the last few years of the nineteenth century. Loeffler and Frosch, appointed to head a commission on foot-and-mouth disease in Germany, made a very thorough study of the disease, ${ }^{48}$ and found its pathogen to pass through bacteria-proof filters. Like Ivanovski, they at first suspected the presence of a soluble toxin; but having inoculated large numbers of calves in series, and having calculated the dilutions which would have taken place had the pathogen not multiplied in its hosts, they were forced to conclude that no toxin could possibly have been sufficiently potent. ${ }^{49}$ To Loeffler and Frosch, both pupils of Koch's, ${ }^{50}$ the only alternative was an agent of bacterial nature, even though its dimensions would have to be considerably smaller than those of any previously described micro-organism. Weight was added to their point of view by a paper published in 1898 by a Paris team, ${ }^{51}$ who found the agent of

12 Ibid., p. 31.

4 Among the outstanding contributions of Beijerinck to botany and microbiology may be mentioned his studies of bacterial root nodules (series of papers in Bot. Ztg., 1888, 46), and his development of the enrichment culture technique (see C. B. van Niel, 'The Delft school and the rise of general microbiology', Bact. Rev., 1949, 13: 161-174, p. 163).

" See for example Dooren de Jong, op. cit., note 25 above, pp. 26-29.

es Ibid., p. 11.

as Jacobus Henricus van't Hoff (1852-1911), who at the age of twenty-two published an epochmaking work on the assymetry of the carbon atom (see Nobel. The man and his prizes, note 119 below, p. 289).

${ }^{7}$ Dooren de Jong, op. cit., note 25 above, p. 11.

48 [F.] Loeffier and [P.] Frosch, 'Berichte der Kommission zur Erforschung der Maul-und Klauenseuche bei dem Institut für Infektionskrankheiten in Berlin', Zent. Bakt. ParasitKde, 1898, Abt. I, 23: 371-391.

0 Ibid., p. 390-391; tetanus toxin served as their basis for comparison.

so Friedrich Loeffler (1852-1915) and Paul Frosch (1860-1928) carried out the investigation while both were employed in Koch's Institut für Infektionskrankheiten in Berlin.

"1 Nocard, Roux, Borrel, Salimbeni and Dujardin-Beaumetz, 'Le microbe de la peripneumonie', Annls Inst. Pasteur, Paris, 1898, 12 : 240-262. 


\section{Lise Wilkinson}

bovine pleuropneumonia to pass through bacteria-proof filters. They were able to grow it in culture, although under rather special conditions, and to make it just visible under the light microscope. Many pathologists felt that this would be possible in time, when the right conditions were found, for the other "filterable viruses" known. Beijerinck had postulated the existence of a pathogen in the form of a "contagium vivum fluidum"; taking into consideration his discussion of replicating and metabolizing molecules, we must assume that what he had in mind was an agent present in stable solution in the cell sap. As the alternative, which he rejected, Beijerinck referred to a "corpuscular" virus, by which he presumably meant a cellular entity. Unfortunately, the result was that, as Bawden put it: “. . . . this suggestion also had its repercussions, for whether or not viruses were particulate was solemnly debated, without anyone apparently asking what they could be if they were not particles of some size or other". ${ }^{22}$

Also in 1899 the American plant pathologist Woods entered the controversy. His contention was different from either Beijerinck's concept of a contagium vivum fluidum or Ivanovski's bacterial theory. Woods attributed tobacco mosaic disease to a pathologic condition in which there was an accumulation of oxidizing enzymes induced, in his view, by unfavourable external conditions $;^{53}$ a theory harking back to humoral pathology but offering no explanation for the apparently limitless transmissibility of the disease. This deficiency was pointed out in 1905 by Hunger, ${ }^{54}$ who made a point of disagreeing with the conclusions arrived at by all previous workers in the field. His objection to Woods' enzyme theory applied equally well to the similar conclusions reached by Heintzel in a thesis submitted at Erlangen in 1900.55 He disposed of Ivanovski's bacterial theory, and also that by Koning, ${ }^{56}$ by showing that he could dissolve the bodies identified by Ivanovski as the causal micro-organism (Fig. 2) by treating the cells with what he called "phenol chlorathydrat" (sic). Since the cell structure as such remained unaffected by this treatment, he concluded that it was unlikely that the bodies could be living bacteria. ${ }^{57}$ Beijerinck's ideas he dismissed on the grounds, safe at the time, that there was insufficient proof. However, when it came to proposing an alternative theory of his own, Hunger relied on speculation rather than proof as much as those whose ideas he had dismissed. He suggested that the virus might be a toxin which was a normal product of cell metabolism in the tobacco plant, usually of no importance, but which under certain conditions of considerably increased metabolic activity would accumulate and cause the disturbances characteristic of mosaic disease. As for its nature and manner of replication, he wrote:

s2 Bawden, op. cit., note 9 above.

s. A. F. Woods, 'The destruction of chlorophyll by oxidizing enzymes', Zent. Bakt. ParasitKde, 1899, Abt. II, 5: 745-754.

54 (a) F. W. T. Hunger, 'Untersuchungen und Betrachtungen über die Mosaikkrankheit der Tabakspfianze', Z. PfKrankh., 1905, 15: 257-311.

(b) F. W. T. Hunger, 'Neue Theorie zur Ätiologie der Mosaikkrankheit des Tabaks', Ber. dt. bot. Ges., 1905, 23: 415-418.

${ }^{56}$ K. G. E. Heintzel, Contagiöse Pflanzenkrankheiten ohne Microben, unter besonderer Berücksichtigung der Mosaikkrankheit der Tabaksblätter. Inaug. Diss., Friedrich Alexander Universität, Erlangen, 1900.

${ }^{56}$ C. J. Koning, 'Die Flecken-oder Mosaikkrankheit des holländischen Tabaks', Z. PfKrankh., 1899, 9:65-80.

57 Hunger, op. cit., note 54a above, p. 264. 


\section{Lessons of the plant viruses-tobacco mosaic virus}

"I assume that the phytotoxin of mosaic disease, which is produced initially in response to external factors, is capable of exercising a physiological contact effect when entering into normal cells, inducing in them a secondary formation of identical toxin, i.e. the mosaic disease toxin has the ability to act in a physiologically autocatalytic manner". ${ }^{.8}$

Even if this explanation does to some extent imply the use of existing cell mechanisms which has ultimately proved to be the cornerstone of virus replication, it is difficult to resist the reflection that Hunger did not noticeably help to clarify the situation. Perhaps his main contribution was to state clearly and categorically what was implied in many papers on the nature of viruses then and later: a belief in the autonomous origin of the pathogen. Hunger wrote: "I consider tobacco mosaic disease to be a pathologic metabolic disturbance which may occur autonomously, but which is nevertheless transmissible". ${ }^{59}$ This view persisted for other virus diseases as well up to the 1930s, reinforced along the way by comparisons with the for so long inexplicable lysogenic properties of the bacterial viruses, or bacteriophages. ${ }^{80}$ As late as $1931 \mathrm{H}$. H. Dale found it necessary to repudiate this view when he wrote of rabies: "It is difficult, again, to imagine that a virus like rabies could be permanently excluded from a country if it had such an autogenous origin. The phenomena of immunity to a virus, and of closely specific immunity to different strains of the same virus, are peculiarly difficult to interpret on these lines." 61

While there was a great deal of activity in the field of filterable viruses in the first decade of the twentieth century, ${ }^{62}$ no more papers on the nature of tobacco mosaic virus have been found between Hunger's two articles in $1905^{63}$ and the outbreak of World War I. Then, between 1915 and 1918 there appeared in the Journal of Agricultural Research a number of papers by $\mathrm{H}$. A. Allard. ${ }^{64}$ In a series of careful experiments he showed that oxidase and peroxidase activities could be selectively destroyed without destroying infectivity, and vice versa, and hence that the agent responsible for tobacco mosaic disease could not belong to either of these categories, as Woods had claimed. ${ }^{65}$ On the other hand, Allard could no more than Woods or Hunger accept Beijerinck's concept, and concluded his cogent study of the properties of the pathogen with the assertion that: "A specific, particulate substance not a normal constituent of healthy plants is the cause of the disease. Since this pathogenic agent is

s8 Ibid., p. 296.

${ }^{50}$ Hunger, op. cit., note $54 \mathrm{~b}$ above, p. 416.

${ }^{\circ}$ For a comprehensive review of the concept of lysogeny and its history, see A. Lwoff, 'Lysogeny', Bact. Rev., 1953, 17: 269-337.

${ }^{61}$ H. H. Dale, 'The biological nature of the viruses', Nature, Lond., 1931, 128: 599-602, p. 601.

"s See L. Wilkinson, 'The development of the virus concept as reflected in corpora of studies on individual pathogens. 1. Beginnings at the turn of the century', Med. Hist., 1974, 18:211-221, p. 217.

os Hunger, op. cit., note 54 above.

on (a) H. A. Allard, 'Effect of dilution upon the infectivity of the virus of the mosaic disease of tobacco', J. agric. Res., 1915, 3:295-299.

(b) H. A. Allard, 'Some properties of the virus of the mosaic diseases of tobacco', ibid., 1916, ii, 6: 649-674.

(c) H. A. Allard, 'The mosaic disease of tomatoes and petunias', Phytopathology, 1916, 6: 328-335.

(d) H. A. Allard, 'Effects of various salts, acids, germicides, etc., upon the infectivity of the virus causing the mosaic disease of tobacco', J. agric. Res., 1918, 13: 619-637.

${ }^{o s}$ Woods, op. cit., note 53 above. 


\section{Lise Wilkinson}

highly infectious and is capable of increasing indefinitely within susceptible plants, there is every reason to believe that it is an ultramicroscopic parasite of some kind". ${ }^{68}$

In Bawden's interpretation ${ }^{67}$ this meant that ". . . for long most people accepted Allard's (1916) conclusion that an organism was the cause". But Bawden did not mention a paper which appeared after Allard's, but before more deliberate attempts began to separate the infective principle from the juice of tobacco mosaic diseased plants from the mid-1920s onward. It was read at the annual meeting of the American Philosophical Society in Philadelphia in 1923, and in almost every way, except perhaps in the strictest chronological sense, did it distinguish the half-way mark in the development of the concept of tobacco mosaic virus as a biological entity. Its authors, Duggar and Karrer Armstrong ${ }^{68}$ had previously worked on this pathogen; now they offered further results of their own, in addition to a comprehensive review of all that had gone before, and in particular of the results in an area which had attracted a lot of attention at a joint meeting of the Botanical Society of America and the American Phytopathological Society only four months earlier. Curious amoeba-like bodies had been observed in the tissues of plants showing symptoms of mosaic disease from the time of Ivanovski (Fig. 2). The nature of such bodies was hotly debated at this time. Some authors believed them to be of a kind with the flagellates normally living in the latex tubes of certain dicotyledons; ${ }^{89}$ others suggested they might be protozoa causing the disease. ${ }^{70}$ Duggar and Armstrong were sceptical, having observed similar structures in healthy tissues. They proceeded to describe results of their own, obtained two years earlier, ${ }^{71}$ when they made an attempt to determine the particle size of the infective agent of tobacco mosaic disease. Using different types of filters, and a series of colloid sols of varying particle size (e.g. casein, gelatin suspensions, lactalbumin, haemoglobin, and dextrin), they concluded that the particle size of their pathogen approximated that of a fresh 1 per cent haemoglobin solution. According to their information this meant a particle size of $30 \mu \mu ; *$ having arrived at this value they concluded that "... its life relations must be very different from those of an organism whose volume relations are to this as 37,000 to 1 or about $1,000,000$ to 26. This would be the relation between the average bacterial plant pathogen and the mosaic virus. Assuming a complex organisation, many theoretical questions would arise for consideration. Among these might be mentioned perhaps above all that of the surface tension conditions in such a structure, also the possibility of organisation at

$* 1 \mu \mu=1 \mathrm{~m} \mu=1 \mathrm{~nm}$.

c6 Allard, op. cit., note 64(b) above, p. 672.

${ }^{67}$ Bawden, op. cit., note 9 above, p. 5.

68 B. M. Duggar and J. Karrer Armstrong, 'Indications respecting the nature of the infective particles in the mosaic disease of tobacco', Ann. Mo. bot. Gdn, 1923, 10: 191-212. More than twenty years later Duggar (1872-1956) in his very active "retirement" when he joined the research laboratories of Lederle, discovered aureomycin (see M. Finland, 'Twenty-fifth anniversary of aureomycin: the place of the tetracyclines in antimicrobial therapy', Clin. Pharmacol. Ther., 1974, 15:3-8).

" See for example A. Lafont, 'Sur la présence d'un Leptomonas parasite de la classe des Flagellés dans le latex de trois Euphorbiaccés', Annls Inst. Pasteur, Paris, 1910, 24: 205-219; and C. Franca, 'La flagellose des Euphorbes', ibid., 1920, 34: 432-465.

${ }^{70} \mathrm{R}$. Nelson, 'The occurrence of protozoa in plants affected with mosaic and related diseases', Techn. Bull. Mich. (St. Coll.) agric. exp. Stn, 1922, 58: 1-30.

71 B. M. Duggar and J. L. Karrer, 'The sizes of the infective particles in the mosaic disease of tobacco', Ann. Mo. bot. Gdn, 1921, 8: 343-356. 


\section{Lessons of the plant viruses-tobacco mosaic virus}

all (membrane existence, etc.) as now comprehended." 72 In this short paragraph we again find ourselves at a half-way mark; twenty years on from the tentative beginnings of biophysical calculations made by McKendrick ${ }^{73}$ and Errera, ${ }^{74}$ and aimed at determining the extent to which reduction of the size of living bodies would be limited by the minimum number of protein molecules required to sustain life processes. At the other extreme, further away in time and sophistication, were to come the lucid considerations, supported by the accumulation of nearly half a century more of revolutionary information, by Pirie ${ }^{75}$ regarding the viability of the $125 \mathrm{~nm}$ particles found in some mycoplasm (the category now including the pleuropneumonia agent) filtrates.

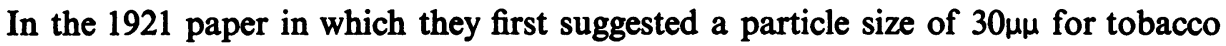
mosaic virus, Duggar and Karrer had felt obliged to add a footnote. Their attention had been drawn, they explained, since they first wrote the paper, to an article in which an attempt had been made to determine the size of another filterable virus. This was Andriewsky's paper on ultrafiltration of fowl plague virus, ${ }^{78}$ in which he came to the conclusion that this pathogen was smaller than haemoglobin molecules for which he quoted a diameter of 2.3-2.5 $\mu$. On this point Duggar and Karrer commented: "In discussing actual size, however, he seems to confuse the sizes of colloidal particles of haemoglobin with the sizes of molecules. Nevertheless, his conclusion is to the effect that this virus cannot be formed of cells similar to those of plants and animals at present known." 77 This remark reflects the uncertainty which at the time surrounded the concepts of colloidal particles, large molecules, aggregates, etc. Andriewsky is not referred to in the 1923 paper. Here, after carefully considering also the "enzyme" theory, the "bacterial" theory, and the "virus" theory, and comparing the effects of grinding on the infectivities of tobacco mosaic virus and of bacterial spores (Bacillus subtilis) respectively, they summed up their findings in the following remarkable paragraph:

Taking into consideration all the facts, we cannot avoid the impression, tentatively, that the causal agency in mosaic disease may be, in any particular case, a sometime product of the host cell; not a simple product such as an enzyme, but a particle of chromatin or of some structure with a definite heredity, a gene perhaps, that has, so to speak, revolted from the shackles of coordination, and being endowed with a capacity to reproduce itself, continues to produce disturbance and "stimulation" in its path, but its path is only the living cell. ${ }^{78}$

Chromatin and achromatin, the brain children of Flemming, ${ }^{79}$ were soon accepted facts in the biochemical literature of the $1880 \mathrm{~s} ;{ }^{80}$ but the possible genetic role of

72 Duggar and Karrer-Armstrong, op. cit., note 68, above, pp. 200-201.

72 J. G. McKendrick, 'President's Address', Rep. Br. Ass. Advmt Sci., September, 1901.

"L. Errera, 'Sur la limite de petitesse des organismes', Bull. Séanc. Soc. roy. Sci. méd. nat. Brux., January 1903; also in Recl. Inst. bot. 'Léo Errera', 1906, 6: 73-82.

${ }^{76}$ N. W. Pirie, 'Introduction: Principles of "mini-life", in Pathogenic mycoplasmas, Ciba Foundation Symposium, Amsterdam, Elsevier, 1972, p. 6.

76 P. Andriewsky, 'L'ultrafiltration et les microbes invisible I. communication: La peste des poules', Zentbl. Bakt. ParasitKde, 1914, Abt. I, Orig., 75: 90-93.

77 Duggar and Karrer, op., cit., note 71 above, footnote p. 355.

${ }^{78}$ Duggar and Karrer Armstrong, op. cit., note 68 above, p. 210.

"Walther Flemming, Zellstubstanz, Kern und Zelltheilung, Leipzig, Verlag von F. C. W. Vogel, 1882 , see p. 129.

${ }^{20}$ In 1885 A. Kossel wrote (A. Kossel, 'Ueber das Adenin', Ber. dt. chem. Ges., 1885, 18: ii; 1928- 


\section{Lise Wilkinson}

chromatin was shrouded in uncertainty for many years. In The path to the double helix, Olby has traced the changing attitudes to what he calls "the vexed chromatin problem"; ${ }^{81}$ curiously enough recognition of its genetic importance appears to have been at rather a low ebb at the time Duggar delivered his address. ${ }^{82}$

By the mid-1920s, biochemistry was coming into its own, and its impact was felt in virus research as elsewhere. Since before World War I there had been those who believed, on the basis of a mixture of comparative experimental work, constructive thought, and faith, that certain viruses had the properties of proteins. Faith and inspired thought were necessary qualifications in those days, when there were few hard facts available within protein chemistry. Mrowka in 1912 had suggested that fowl plague virus might be a globulin. ${ }^{83}$ Even more perceptively, and using essentially an approach later to be developed very successfully, Sanfelice in 1914 showed that he could precipitate the active principle of fowl-pox out of infected material and resuspend it, without losing infectivity, by the chemical methods used for isolation of nucleoproteins. He drew the obvious conclusion: the virus of fowl-pox was a nucleoprotein; although there is no evidence that he was familiar with Beijerinck's work on tobacco mosaic virus, he also suggested for fowl-pox virus a manner of replication which was dependent on the existing mechanism of the infected cell. ${ }^{84}$ Beijerinck himself, who never published another paper on tobacco mosaic virus after 1899, restated his position in 1922 in a casual remark while commenting on d'Hérelle's work on bacteriophage: "In my opinion, the dialysis test proves quite clearly that Bacteriophagus is of the same order of magnitude as the protein molecule and that the name of "contagium vivum fluidum" which I gave to the virus of mosaic disease long ago, fittingly expresses this conception."85 From the early 1920s onwards, tobacco mosaic virus reassumed its role as a model plant virus, gradually becoming also the plant virus from which so many lessons were learnt about viruses of vertebrates. But in the 1920s, there were still many basic questions left unanswered, and consequently much room left for speculation and the launching of ideas, some of which appear rather curious when viewed with the benefit of hindsight.

Histological studies of diseased tissues have always provided ample material for discussion and argument. Ivanovski had observed different types of characteristic bodies in the cells of mosaic diseased plants, and meticulously recorded his observations (Fig. 2). Von Prowazek, in spite of being an erstwhile botanist, had concentrated his histological studies, which produced the chlamydozoa concept, ${ }^{86}$ on inclusion

1930, p. 1929): ". . . a substance which the histologists call chromatin . . . . As we know from the studies of Zacharias, this substance is identical with the nuclein long familiar to chemists." (Eduard Zacharias' papers on the subject were published in Bot. Ztg in the early 1880s, see for example 'Ueber den Zellkern', Bot. Ztg, 1882, 40: 651-664).

1 R. Olby, The path to the double helix, London, Macmillan Press, 1974, p. 102.

s2 Ibid.

23 Mrowka, 'Das Virus der Hühnerpest ein Globulin', Zentbl. Bakt. ParasitKde, 1912, Abt, I, Orig., 67:249-298.

8 F. Sanfelice, 'Untersuchungen über das Epithelioma contagiosum der Tauben', Z. Hyg. InfektKrankh., 1914, 76: 257-279, see p. 279.

${ }^{e s}$ M. W. Beijerinck, 'Pasteur en de ultramicrobiologie', Chem. Weekbl., 1922, 19: 525-527, p.527.

${ }^{86} \mathrm{~L}$. Wilkinson and A. P. Waterson, 'The development of the virus concept as reflected in corpora of studies on individual pathogens. 2. The agent of fowl plague-a model virus?', Med Hist., 1975, 19: 52-72, p. 55. 


\section{Lessons of the plant viruses-tobacco mosaic virus}

bodies formed in diseases of animals and man, and ignored plant diseases. In the early 1920 s, others sought to apply cytological methods to the study of plant disease, and of tobacco mosaic disease in particular. B. T. Palm, from the isolation of a Dutch research station in Sumatra, asked: "Is the mosaic disease of tobacco a chlamydozoonose?" 87 If others did not ask the question quite so explicitly, there was no dearth of papers reporting the presence of foreign bodies in the tissues of various plants affected by mosaic diseases. L. O. Kunkel, a sober and experienced plant pathologist who, ten years later, as director of the Rockefeller Institute's Division of Plant Pathology, was to launch the young Wendell Stanley on a biochemical quest for the agent of tobacco mosaic disease, was careful not to attach too much significance to the plasma-like bodies and cells filled with granular matter which he found in affected tissues of corn and Hippeastrum. ${ }^{88}$

Then at a joint meeting of the Botanical Society of America and the American Phytopathological Society at Boston in 1922, Ray Nelson announced "The occurrence of protozoa in plants affected with mosaic and related diseases". It was an impressive account supported by a number of photomicrographs of flagella-like bodies in phloem tissues of mosaic diseased bean plants. Nelson was convinced they were flagellates; he compared them to what he considered to be related types of Leptomonas and Trypanosomes, ${ }^{89}$ and claimed to have observed them undergoing longitudinal fission. He also insisted that healthy tissues contained no similar structures, a statement contested less than a year later by Duggar and Armstrong,90 who confirmed the occurrence of objects of such appearance, but who found them in healthy as well as in diseased tissues, and who were not at all convinced that they were protozoa, or indeed foreign bodies at all. There was little support forthcoming for the flagellate notion in subsequent years. Goldstein studied what she named the $\mathrm{x}$-bodies, found by her in tobacco plants $^{91}$ and in the leaves of dahlia plants affected with mosaic disease when they showed mottling. ${ }^{92}$ These bodies, described as lying in "close proximity to the nucleus of the cell, pressed up against it, or partially surrounding it" and being "notably amoeba-like in appearance", were similar to those observed in mosaic diseased tobacco leaves by Ivanovski (Fig. 2) and by Hunger. ${ }^{93}$ Goldstein thought the $x$-bodies might be "plastic enough to pass through the pores of anti-bacterial filters", and sought to identify them with the causal agent of the mosaic diseases. ${ }^{94}$ The structures of these types of inclusion bodies continued to puzzle plant pathologists. Helen Purdy Beale considered them coincidentally in a study of the crystalline intracellular deposits in relation to Stanley's

87 B. T. Palm, 'De Mosaikziekte van de Tabak een Chlamydozoonose', Bull. Deli Proefstn. Medan, 1922, 15: 1-10.

os L. O. Kunkel, 'Ameboid bodies associated with Hippeastrum mosaic', Science, N.Y., 1922, 55: 73.

Nelson, op. cit., note 70, above, p. 24.

"Duggar and Karrer Armstrong, op. cit., note 68 above.

91 (a) B. Goldstein, 'A cytological study of living cells of tobacco plants affected with mosaic disease', Bull. Torrey bot. Club, 1924, 51 : 261-274.

(b) B. Goldstein, 'A cytological study of the leaves and growing points of healthy and mosaic diseased tobacco plants', ibid., 1926, 53: 499-599.

'2 B. Goldstein, 'The x-bodies in the cells of dahlia plants affected with mosaic disease and dwarf', ibid., 1927, 54: 285-293.

Hunger, op. cit., note 54 above.

" Goldstein, op. cit., note 92, above p. 290. 


\section{Lise Wilkinson}

"crystalline tobacco-virus protein" in 1937;95 Bawden retained a life-long interest in them. ${ }^{96}$ In recent years interest in cytoplasmic inclusions associated with plant virus diseases has focused in particular on the so-called pinwheel inclusions characteristic of viruses of the potato virus $Y$ group, which appear to consist largely of protein unrelated to the virus protein.97

During the 1920s, the question of artificial culture of the virus also came up for renewed consideration. Olitsky claimed to have successfully cultivated tobacco mosaic virus in cell-free filtrates of the pulp from all vegetative parts of healthy young tomato plants; ${ }^{98}$ but Mulvania, ${ }^{99}$ Goldsworthy ${ }^{100}$ and Beale ${ }^{101}$ were all unable to reproduce his results.

Mulvania had every reason for reacting so swiftly to Olitsky's experiments on cultivation. He was already deep into his own investigations on the agent of tobacco mosaic disease, and the following year published a major study on the nature of this virus. ${ }^{102}$ Like Allard ${ }^{103}$ before him, he was concerned with the chemical properties of the mosaic disease agent; working a decade later, he benefited from the advances made in biochemical knowledge and techniques in the meantime. Also, significantly, Mulvania was familiar with the papers published by Mrowka ${ }^{104}$ and Andriewsky ${ }^{105}$ on the eve of World War I, in which they suggested that the agent of an animal virus disease, viz., fowl plague, had the characteristics of a simple globulin molecule. Mulvania may have been influenced in his approach by James Johnson, ${ }^{108}$ under whose direction the study was made. Certainly it was unusual at this time to find references to papers on animal viruses in studies on plant viruses. The traffic seemed to be all the other way, tobacco mosaic virus having merited inclusion in articles on viruses of animals and $\operatorname{man}^{107}$ ever since the appearance of the first papers by Ivanovski and Beijerinck before the turn of the century.

${ }^{95} \mathrm{H}$. P. Beale, 'Relation of Stanley's crystalline tobacco-virus protein to intracellular crystalline deposits', Contr. Boyce Thomson Inst. Pl. Res., 1937, 8: 413-431.

${ }^{26}$ N. W. Pirie, 'Frederick Charles Bawden 1908-1972', Biogr. Mem. Fellows R. Soc. Lond., 1973, 119: $19-63$.

${ }^{\text {97 }}$ E. Hiebert, D. E. Purcifull, R. G. Christie and S. R. Christie, 'Partial purification of inclusions induced by tobacco etch virus and potato virus $Y$ ', Virology, 1971, 43: 638-646.

${ }^{\circ 8} \mathrm{P}$. K. Olitsky, 'Experiments on the cultivation of the active agent of mosaic disease in tobacco and tomato plants', J. exp. Med., 1925, 41: 129-136.

'M. Mulvania, 'Cultivation of the virus of tobacco mosaic by the method of Olitsky', Science, N.Y., 1925, 62: 37.

${ }_{100}$ M. C. Goldsworthy, 'Attempts to cultivate the tobacco mosaic virus', Phytopathology, 1926, 16: 873-875.

${ }^{101}$ H.P. Beale, 'Attempt to cultivate an organism from tomato mosaic', Bot. Gaz., 1926, 81 : 210-217.

${ }^{102}$ M. Mulvania, 'Studies on the nature of the virus of tobacco mosaic', Phytopathology, 1926, 16: 853-871.

${ }^{103}$ Allard, op. cit., note 64 above.

100 Mrowka, op. cit., note 83 above.

${ }^{105}$ Andriewsky, op. cit., note 76 above.

108 James Johnson (1886-1952) spent a lifetime working to improve the decreasing yields of tobacco in his home state of Wisconsin; in addition to diseases of the tobacco plant he also studied aspects of nutrition and resistance (obit., Phytopathology, 1954, 44: 335-336). Five years earlier Johnson had studied the effect of temperature on the course of certain plant diseases, among them tobacco mosaic (J. Johnson, 'The relation of air temperature to certain plant diseases', ibid., 1921, 11: 446-458).

${ }^{107}$ See for example the early reviews by E. Roux, "Sur les microbes dits "invisibles"', Bull. Inst. Pasteur, Paris, 1903, 1: 7-13, 49-56; and by P. Remlinger, 'Les microbes filtrants', ibid., 1906, 4: 337-345, 385-392. 


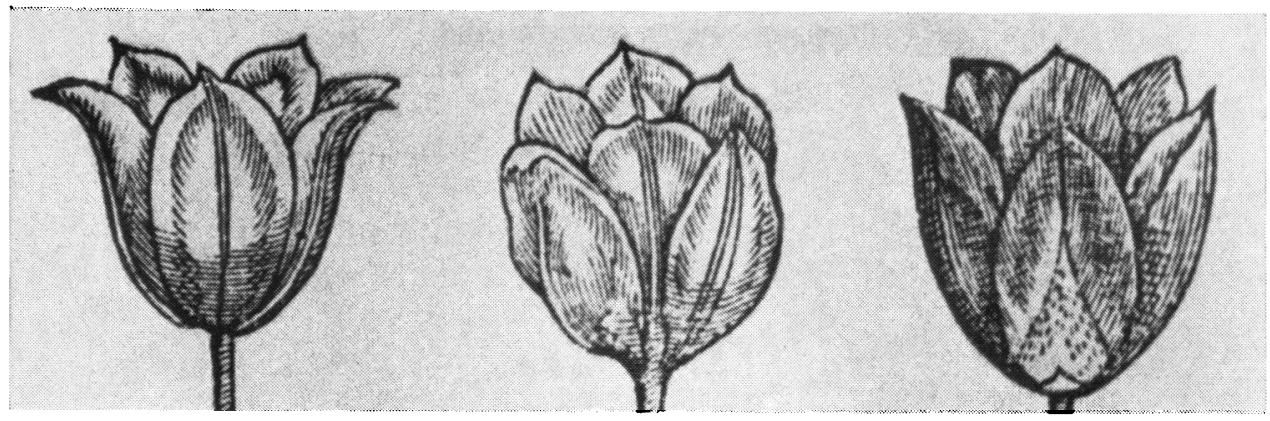

Figure 1

Woodcuts depicting variegated tulip flowers according to Clusius (1583) and Gerard (1597); cf. note 11.

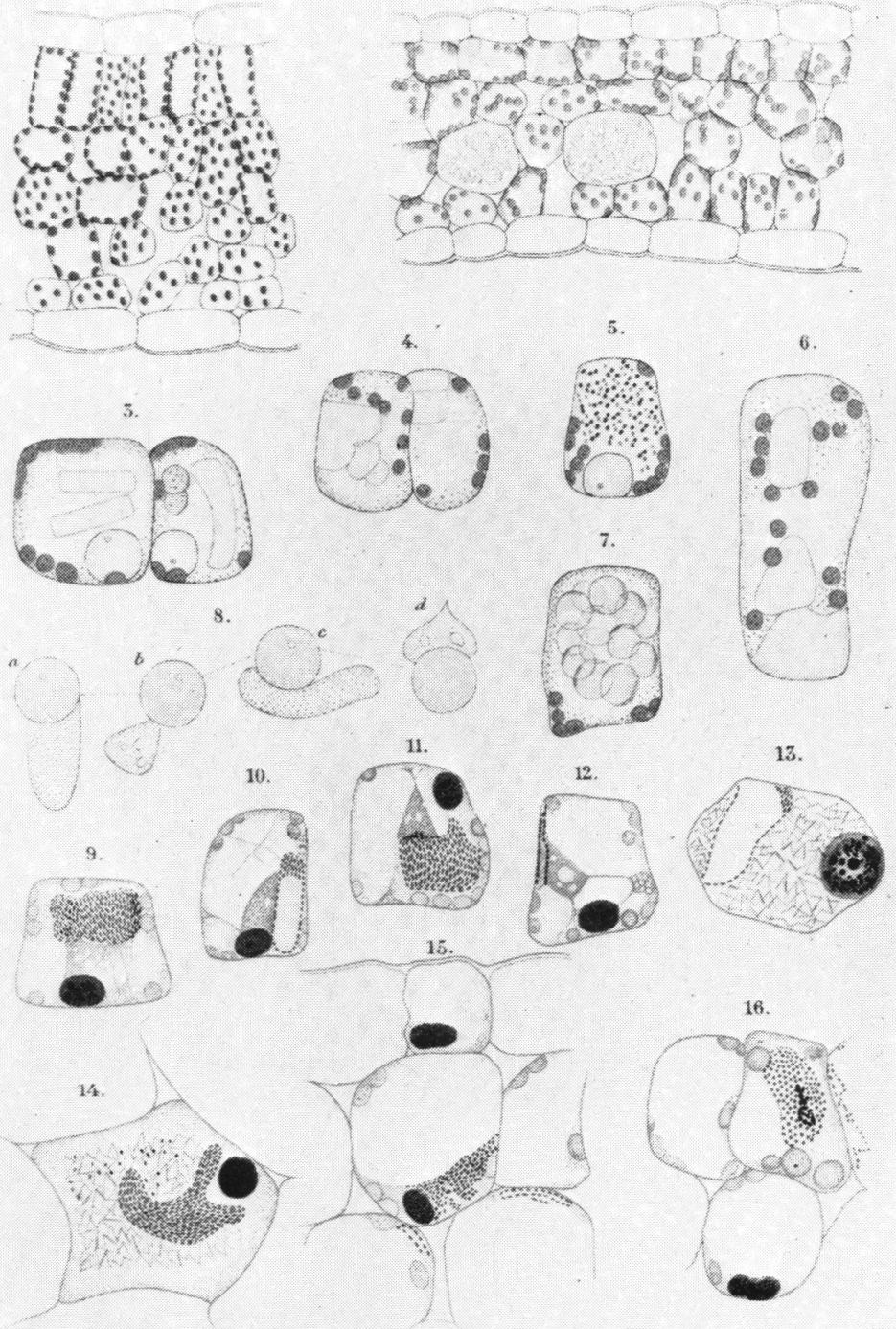

Figure 2. in Z. PflKrankh., 1903 (note 33). 


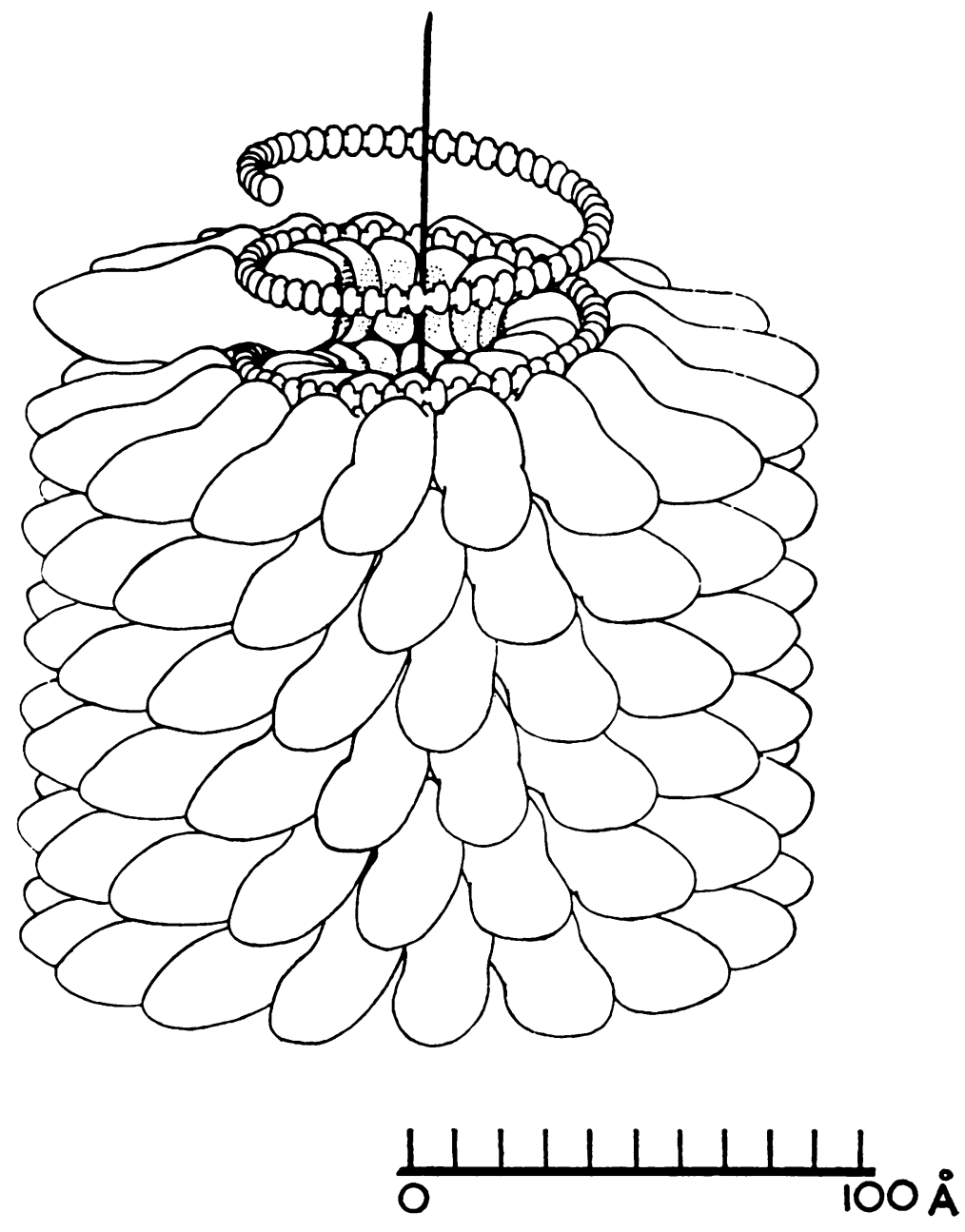

Figure 3.

The virion of tobacco mosaic according to Franklin, Klug, Caspar and Holmes (note 167). 


\section{Lessons of the plant viruses-tobacco mosaic virus}

Mulvania made no actual attempt to precipitate the virus out of infected fluid as Mrowka and Andriewsky had done; but he recorded the effects of a number of carefully selected treatments on the infectivity of the virus. The treatments included exposure to light (sunlight, ultraviolet light, $\mathrm{X}$-rays) and heat, injection of the virus into the bloodstream of a rabbit, testing its dialysability, and finally testing the possible ability of a number of bacteria to inactivate the virus. Although he found tobacco mosaic virus to tolerate higher temperatures than the animal viruses tested by others, ${ }^{108}$ he concluded, referring to the results of Mrowka and of Andriewsky with fowl plague virus: "It is not impossible that the mosaic virus of tobacco may be of a similar nature, that is, a protein of a very simple kind, having the characteristics of an enzyme". ${ }^{109}$ When he inoculated rabbits with tobacco mosaic virus, Mulvania was content to observe that the virus was inactivated within thirty minutes and that there was no detectable reaction on the part of the rabbit. Drawn blood of the rabbit also inactivated the virus in mixture with infected plant juice. Mulvania does not appear to have considered the mechanism of inactivation, beyond the laconic statement "It is, of course, well-known that non-pathogenic bacteria soon disappear from the blood of animals which have received them into their circulation".110 But separated from Mulvania's paper by only a few pages of the 1926 volume of Phytopathology, Goldsworthy wrote on 'Studies on the spot disease of cauliflower; a use of serum diagnosis'. Spot disease of cauliflower is a bacterial disease; Goldsworthy explained his technique as follows: "The writer, taking advantage of the high specificity of antibodies, as used by medical bacteriologists, has brought into use the agglutinating antiserum in his present study. High titre antisera were produced by injecting into rabbits the appropriate antigen, namely, the organism under study."111 The following year Dvorak initiated the use of serological techniques in plant virus research $;^{112}$ the potential of this approach was explored and developed for quantitative work in subsequent years by Helen Purdy Beale at the Boyce Thompson Institute. ${ }^{118}$

Beale's work was of particular importance at this stage, for the absence of reliable methods for assaying virus preparations had been a stumbling-block in much early work on plant viruses. In $1928 \mathrm{~F}$. O. Holmes took the first step towards a solution to the problem when he realized that the necrotic lesions produced in Nicotiana glutinosa after infection with tobacco mosaic virus could give a quantitative indication of the relative infectivity of the inoculum used.114 The method was gradually

${ }^{108}$ Mulvania, op. cit., note 102 above, Table 16, p. 866.

100 Ibid., p. 869.

110 Ibid., p. 859.

111 M. C. Goldsworthy, 'Studies on the spot disease of cauliflower; a use of serum diagnosis', Phytopathology, 1926, 16: 877-883.

112 M. Dvorak, 'The effect of mosaic on the globulin of potato', J. Infect. Dis., 1927, 41: 215-221.

118 (a) H.P. Beale, 'Immunologic reactions with tobacco mosaic virus', Proc. Soc. exp. Biol. Med., 1928, 25: 702-703.

(b) H. P. Beale, 'Immunologic reactions with tobacco mosaic virus', J. exp. Med., 1929, 49: 919-936.

(c) H. P. Beale, 'Specificity of the precipitin reaction in tobacco mosaic disease', Contr. Boyce Thomson Inst. Pl. Res., 1931, 3: 529-539.

${ }_{114}$ F. O. Holmes, 'Accuracy in quantitative work with tobacco mosaic virus', Bot. Gaz., 1928, 86: 66-81. 


\section{Lise Wilkinson}

perfected, ${ }^{115}$ and is still a very useful tool, comparable to the plaque titration method for the assay of animal viruses. ${ }^{116}$

Mulvania had shown in 1926 that the agent of tobacco mosaic disease behaved in many ways like a protein, possibly with characteristics similar to those of enzymes. Also in 1926, J. B. Sumner at Cornell had succeeded in preparing crystals of urease by simply grinding meal of Canavalia ensiformis beans (as it turned out, of a strain particularly rich in urease) with dilute acetone and chilling the filtrate from the suspension. ${ }^{117}$ The substance could be recrystallized without losing any of its activity, and turned out to be a protein, with a molecular weight of $483,000 .{ }^{118}$ Although Sumner's results were at first met with scepticism, ${ }^{119}$ a climate was building up in which plant pathologists and biochemists were considering the possibilities of isolating viruses by chemical means, possibly even in the form of crystalline protein.

The problem which had first to be tackled in order to apply chemical methods of identification was that of purification and concentration of the virus. Already before the turn of the century, the resourceful Beijerinck had shown that alcoholic precipitation would leave the active principle of tobacco mosaic disease intact. ${ }^{120}$ Allard in 1916 confirmed that the virus would precipitate out of its solution if ethyl alcohol was added to a concentration of $\mathbf{4 5}$ per cent; on the other hand, high concentrations destroyed activity. ${ }^{121}$ In $1926 \mathrm{M}$. N. Walker developed this approach in a comparative study of mosaic diseases of various plants. ${ }^{122} \mathrm{He}$ added absolute alcohol to the infected plant juices to obtain different concentrations of alcohol, and in all cases he obtained a "light flocculent precipitate" which he could separate out by centrifuging, and which upon resuspension in water remained a satisfactory infective inoculum for young healthy plants.

The following year, H. H. McKinney tackled the question of purification and quantification, and emphasized the need for standardization of the methods used. ${ }^{123}$ G. C. Vinson who also published his first results in 1927, ${ }^{124}$ introduced precipitating agents other than alcohol, beginning with safranine in aqueous solution. With A. W. Petre, Vinson then embarked on a methodical study of the possibilities of precipitating tobacco mosaic virus out of infected juice by means of various metal and ammonium salts. ${ }^{125}$ In the end, they found a method based on the use of lead acetate as precipitant the most satisfactory. This method allowed them to isolate crystals which could be

${ }^{115}$ F. O. Holmes, 'Local lesions in tobacco mosaic', ibid., 1929, 87: 39-55.

${ }_{116}$ See A. P. Waterson, Introduction to animal virology, Cambridge University Press, 1968, pp. 46-52.

${ }_{117} \mathrm{~J}$ J. B. Sumner, 'The isolation and crystallization of the enzyme urease', J. biol. Chem., 1926, 69: 435-441, and 'Note. The recrystallization of urease', ibid., 1926, 70: 97-98.

${ }_{118} \mathrm{~J}$. B. Sumner, N. Gralén and I. Eriksson-Quensel, 'The molecular weight of urease', ibid., 1938, 125: 37-44.

${ }^{110}$ See for example Nobel. The man and his prizes, Nobel Foundation and W. Odelberg (eds.), New York, American Elsevier, 1972, p. 376.

130 Beijerinck, op. cit., note 31 above, p. 32.

${ }^{121}$ Allard, op. cit., note 64 (b) above.

122 M. N. Walker, 'A comparative study of the mosaic diseases of cucumber, tomato and Physalis', Phytopathology, 1926, 16: 431-458.

${ }_{122}$ H. H. McKinney, 'Quantitative and purification methods in virus studies', J. agric. Res., 1927, 35: 13-38.

${ }_{124}$ C. G. Vinson, 'Precipitation of the virus of tobacco mosaic', Science, N.Y., 1927, 66: 357-358.

${ }^{125}$ C. G. Vinson and A. W. Petre, 'Mosaic disease of tobacco I. Progress in freeing the virus of accompanying solids', Bot. Gaz., 1929, 87: 14-38. 


\section{Lessons of the plant viruses-tobacco mosaic virus}

shown to have retained moderate infectivity, ${ }^{126}$ but the ash content was high, and there was considerable loss of activity on recrystallization. Vinson and Petre were forced to conclude that their crystals in no way represented pure virus. On the other hand, it was becoming increasingly clear from this work as well as that of others ${ }^{127}$ that chemical methods were having an impact; and that the once vague and not particularly well-documented suggestions that viruses might have the characteristics of protein molecules, or enzymes, could be more than mere wishful thinking.

With faultless timing, and world recession notwithstanding, the Rockefeller Foundation chose the year 1931 to open a new Division for Plant Pathology at Princeton. L. O. Kunkel went from the Boyce Thompson Institute, where he had been in charge of the department in which Vinson worked, to be its first director. ${ }^{128}$ One of his new recruits was a young chemist just returned from postgraduate studies in Germany. ${ }^{129}$ His name was Wendell M. Stanley, he was able and enthusiastic, and his brief was to apply his chemical knowledge to the thorny problem of purification of tobacco mosaic virus. As Stanley himself later recalled it, ${ }^{130}$ he set out methodically evaluating the work done so far by others, and soon decided that Vinson and Petre's lead acetate method offered the most promising possibilities. Almost from the beginning, he was convinced that the nature of the virus was that of a protein molecule. He was of course familiar with the work recently carried out by another Rockefeller employee, J. H. Northrop, who had confirmed and extended Sumner's successful crystallization of enzymes. ${ }^{131}$ By 1934 it was obvious to Stanley that, in his own words: "the methods of protein chemistry so successfully used by Northrop and associates in their work on enzymes might prove useful in work with this virus". ${ }^{132}$ A year later, Stanley could announce his successful preparation of "A crystalline protein possessing the properties of tobacco mosaic virus". ${ }^{133} \mathrm{He}$ also announced his analytical results which showed that his virus "protein" contained an unprecedented 20 per cent nitrogen. Among those who found this figure surprisingly high were F. C. Bawden and N. W. Pirie. They decided to look for themselves at the chemistry of tobacco mosaic virus, and they enlisted the help of the Cambridge

126 C. G. Vinson and A. W. Petre, 'Mosaic disease of tobacco II. Activity of the virus precipitated by lead acetate', Contr. Boyce Thomson Inst. Pl. Res., 1931, 3: 131-145.

187 In 1933 Barton-Wright and McBain claimed to have isolated a white crystalline compound containing no nitrogen (E. Barton-Wright and A. M. McBain, 'Possible chemical nature of tobacco mosaic virus', Nature, Lond., 1933, 132: 1003-1004). Caldwell (J. Caldwell, 'Possible chemical nature of tobacco mosaic virus', ibid., 1934, 133: 177) was soon able to point out that their crystals consisted of potassium phosphate and that the virus activity was retained only as an impurity.

${ }_{18 s}$ F. O. Holmes, 'Loujs Otto Kunkel 1884-1960', Phytopathology, 1960, 50: 777-778.

180 See 'Wendell Meredith Stanley', Nature, Lond., 1971, 233: 149-150.

100 W. M. Stanley, 'Biochemistry and biophysics of viruses', in Handbuch der Virusforschung, $\mathbf{R}$. Doerr and C. Hallauer (eds.), Vienna, Julius Springer, 1938, p. 472.

${ }^{181}$ (a) J. H. Northrop, 'Crystalline pepsin I. Isolation and tests of purity', J. gen. Physiol., 1930, 13: 739-766.

(b) J. H. Northrop, 'Crystalline pepsin II. General properties and experimental methods', ibid., 1930, 13: 767-780.

(c) J. H. Northrop, 'Crystalline pepsin III. Preparation of active crystalline pepsin from inactive denatured pepsin', ibid., 1931, 14: 713-724.

${ }^{182}$ Stanley, op. cit., note 130 above.

$123 \mathrm{~W}$. M. Stanley, 'Isolation of a crystalline protein possessing the properties of tobacco-mosaic virus', Science, N.Y., 1935, 81 : 644-654. 


\section{Lise Wilkinson}

crystallographers J. D. Bernal and I. Fankuchen. The following year they could publish their own data in Nature, on 'Liquid crystalline substances from virus infected plants'. Their analytical results differed from Stanley's; they wrote: "These proteins, when precipitated with acid and dried, have the usual analytical figures: $C 51$ per cent; H 7.1 per cent., N 16.7 per cent. The sulphur contents vary from 0.2 to 0.7 per cent and there is 0.5 per cent phosphorus and 2.5 per cent carbohydrate. The last two constituents can be isolated as nucleic acid of the ribose type from protein denatured by heating ....".184

Stanley was at first reluctant to give up his conviction that his crystalline virus was a protein molecule; but by 1938 he had accepted most of the ideas put forward by Bawden and Pirie and wrote: "The first sample of virus protein prepared by Stanley by a method which involved subjecting the protein to considerable fractionation and treatment at fairly acid and alkaline reactions was not found to contain chemically detectable amounts of phosphorus or sulphur. However, samples prepared later by methods involving less fractionation and less drastic changes of hydrogen ion concentration were found to contain both elements. Bawden and Pirie also found the protein which they obtained by chemical methods to contain phosphorus and sulphur . . .". ${ }^{135}$ Pirie himself has recently summed up this interlude rather more succinctly: "The properties that we attributed to TMV [tobacco mosaic virus] differed radically from those that Stanley had attributed to it in 1935. During the next few years he incorporated most aspects of our descriptions into his. This unanimity helped to speed virus research, but leaves unanswered the question of what it was that he isolated in 1935". ${ }^{186}$ Perusal of the literature bears out Pirie's remark; but Stanley received a share of the 1946 Nobel Prize for chemistry for "Preparation of virus proteins in pure form". ${ }^{187}$ And when he was awarded the Franklin medal in 1948 the citation mentioned his "discovery that a virus can be a nucleoprotein ...". 188

While in the 1920s and early 1930 s most of the running in the field of tobacco mosaic virus had been done in the United States, where tobacco farming is important to the national economy, in Britain attention to plant virus disease had focused to a large extent on the potato plant. Odd though it may sound, the man who pioneered potato virus research in Britain was a young physician only four years out of medical school. In an obituary many years later (he lived to be eighty), "S.W." wrote: “ . . I never knew him as a scientist and often wondered how a man of such obviously high intelligence and delicate sensibility could have given up the study of man to devote himself to the potato; but he was very good at potatoes ...". ${ }^{139}$ Illness originally forced $R$. N. Salaman to interrupt his medical career; having recovered, he nevertheless resolved to retire to the country and devote himself to a less strenuous career in plant pathology, eventually establishing the Potato Virus Research Station at Cambridge in 1927. To this station came the young Bawden straight from research on cereal rusts, in 1930.

184 F. C. Bawden, N. W. Pirie, J. D. Bernal and I. Fankuchen, 'Liquid crystalline substances from virus infected plants', Nature, Lond., 1936, 138: 1051-1052.

${ }^{123}$ Stanley, op. cit., note 130 above, pp. 502-503.

186 Pirie, op. cit., note 96 above, p. 41.

137 Nobel. The man and his prizes, op. cit., note 119 above, p. 377.

128 See 'Awards', Science, N.Y., 1948, 108: 406.

180 'Redcliffe Nathan Salaman', Lancet, 1955, i, 268: 1333-1334. 


\section{Lessons of the plant viruses-tobacco mosaic virus}

Association with Salaman led to contacts with many people working on plant viruses at that time; but probably most important of all, at Cambridge began his long collaboration with Pirie. In 1935 Bawden was about to move from Cambridge to Rothamsted, and he and Pirie were beginning a closer collaboration. Apparently the fact that it had to become a long-distance collaboration did, if anything, sharpen and improve it. ${ }^{140}$ It seems that the appearance of Stanley's first paper on crystalline virus preparations galvanized them into action, and caused them to transfer some of their attention from potato virus " $X$ "141 to tobacco mosaic virus and other viruses causing mosaic diseases in plants. ${ }^{142}$ The labels " $X$ " and " $Y$ " for potato viruses had been introduced by Kenneth M. Smith, ${ }^{143}$ who was associated with Salaman's potato virus research at an early stage. 144

When war broke out in 1939, it had been established that a number of plant viruses behaved as nucleoproteins; but although comparisons were drawn between viruses and chromosomes, ${ }^{145}$ the implications were far from clear, and could not be clear, since the nature of genetic determination within the cell remained in question. ${ }^{146}$ Nevertheless, although the years between the outbreak of World War II in 1939 and its conclusion in 1945 did nothing to accelerate work in academic disciplines, it probably did not arrest virus work to any great extent, and valuable papers and suggestions continued to appear. A milestone in work on genetic determination, and ultimately also in work on the nature of viruses, was the now famous paper by Avery, MacLeod and McCarty on the transformation of pneumococcal types, which appeared in 1944. ${ }^{147}$ Unfortunately, this paper achieved due recognition far too slowly; sadly, Avery did not live to see it fully recognized. ${ }^{148}$

Meanwhile, virus research moved on. In 1942, Bawden wrote in Nature on 'Crystallography and plant viruses': "Of the many techniques introduced into research on viruses during recent years, none has aroused more interest than those of the

${ }^{140}$ Pirie, op. cit., note 96 above, p. 23.

141 F. C. Bawden and N. W. Pirie, "Experiments on the chemical behaviour of potato virus " $X$ " ', Br.J. exp. Path., 1936, 17: 64-74.

142 (a) F. C. Bawden and N. W. Pirie, 'Liquid crystalline preparations of cucumber viruses 3 and 4', Nature, Lond., 1937, 139: 546-547.

(b) F. C. Bawden and N. W. Pirie, 'The isolation and some properties of liquid crystalline substances from solanaceous plants infected with three strains of tobacco mosaic virus', Proc. R. Soc. B., 1937, 123: 274-320.

${ }^{143} \mathrm{~K}$. M. Smith, 'On the composite nature of certain potato virus diseases of the mosaic group as revealed by the use of plant indicators and selective methods of transmission', ibid., 1931, 109: 251-267.

$14 \mathrm{~K}$. M. Smith later became director of the virus research unit of the Agricultural Research Council at Cambridge from 1939 until he retired in 1959.

${ }^{145}$ (a) W. T. Astbury, 'Protein and virus studies in relation to the gene', Int. Conf. Genet., 1939, 7: 49-51.

(b) C. D. Darlington, 'Heredity, development and infection', Nature, Lond., 1944, 154: 164-169.

${ }_{146}$ Astbury, op, cit., note 145(a) above, p. 51.

167 O. T. Avery, C. M. MacLeod, and M. McCarty, 'Studies on the chemical nature of the substance inducing transformation of pneumococcal types: Induction of transformation by a desoxyribonucleic acid fraction isolated from Pneumococcus Type III', J. exp. Med., 1944, 79: 137-157.

118 Nobel. The man and his prizes. op. cit., note 119 above, p. 201 : "Thus, Avery's discovery in 1944 of DNA as carrier of heredity represents one of the most important achievements in genetics, and it is to be regretted that he did not receive the Nobel prize. By the time dissident voices were silenced, he had passed away." Avery died in 1955 (obits. Lancet, 1955, i: 463, 571 : Biogr. Mem. Fellows R. Soc., $1956,2: 35-48)$. 


\section{Lise Wilkinson}

crystallographer . . ."149 More than anything this was a reference to the work of Bernal and Fankuchen who had collaborated with Bawden and Pirie on that first joint paper on liquid crystalline viruses in 1936. ${ }^{150}$ In 1941 Bernal and Fankuchen had this to say on the biological significance of their X-ray and crystallographic studies of plant virus preparations: "It has been demonstrated that linear colloidal particles are arranged, even in dilute solution, in aggregates as regular as those of a crystal .... The viruses of the tobacco mosaic type owing to their extreme uniformity and stability are indeed an ideal material for the controlled studies of colloids." 151 But they concluded with a stern warning against too much optimism: ".. it must be emphasized that with such a bewildering set of new phenomena, the work here recorded represents only a preliminary and rough survey and that many more man-years of work will be required before exact and reliable interpretations can be expected".

Those many man-years were reduced to a reasonable number of absolute years because so many men in so many groups of different nationalities now entered the field. It is quite surprising to realize just how well communications functioned in the academic world even between the feuding nations even at the height of that most devastating of wars. In the 1946 volume of Biologisches Zentralblatt there appeared a paper, received for publication in February 1945, its three authors all working at the Kaiser Wilhelm Institut, Berlin-Dahlem. Somehow, throughout the hostilities, scientific journals must have come through. For although their work is in a sense an extension of previous work of Friedrich-Freksa's on chromosomes, ${ }^{152}$ it is also quite clearly influenced by, and indeed refers to at some length, the above paper by Bernal and Fankuchen, ${ }^{163}$ and also other work published during the war years in Nature and the British Journal of Experimental Pathology. ${ }^{154}$ The authors confirmed, and in fact reproduced, Bernal and Fankuchen's model of tobacco mosaic virus. ${ }^{155}$ Comparing parallel mutants of tobacco mosaic virus which induced similar symptoms in tobacco plants, they found them also to deviate in similar ways electrophoretically from the parental type. The difference in electrophoretic response corresponded to differences in amino acid composition.

Since their first study of the X-ray diffraction pictures in 1936,156 Bernal and Fankuchen had devoted much time and effort to the determination of the size of the subunits constituting the tobacco mosaic virus particle. ${ }^{157}$ Their estimate of a molecular

149 F. C. Bawden, 'Crystallography and plant viruses', Nature, Lond., 1942, 149: 321-322.

${ }^{150}$ Bawden et al., op. cit., note 134 above.

151 J. D. Bernal and I. Fankuchen, '1. Introduction and preparation of specimens. 2. Modes of aggregation of the virus particles 3. X-ray crystallographic studies of plant virus preparations', J. gen. Physiol., 1941, 25: 111-165.

${ }_{152} \mathrm{H}$. Friedrich-Freksa, 'Bei der Chromosomenkonjugation wirksame Kräfte und ihre Bedeutung für die identische Verdopplung von Nucleoproteinen', Naturwissenschaften, 1940, 28: 376-379.

${ }^{163}$ Bernal and Fankuchen, op. cit., note 151 above.

154 E.g., A. Kleczowsky, 'Quantitative studies on the serological reactions of some plant viruses and of a pea nodule bacterium (Rhizobium leguminosarum)', Br. J. exp. Path., 1941, 22: 44-58; and Darlington, op. cit., note 145(b) above.

${ }^{155} \mathrm{H}$. Friedrich-Freksa, G. Melchers, and G. Schramm, 'Biologischer, chemischer und serologischer Vergleich zweier Parallelmutanten phytopathogener Viren mit ihren Ausgangsformen', Biol. Zentbl., 1946, 65: 187-222.

${ }_{156}$ Bawden et al., op. cit., note 134 above.

157 Bernal and Fankuchen, op. cit., note 151 above. 


\section{Lessons of the plant viruses-tobacco mosaic virus}

weight of 370,000 for the subunits agreed reasonably well with results obtained by Schramm who had found, in 1943, that chemical treatment at $\mathrm{pH}$ values above 9 would cause tobacco mosaic virus to decompose into subunits of a molecular weight of 360,000. ${ }^{158}$ Friedrich-Freksa, Melchers and Schramm had found the molecular weight of the intact tobacco mosaic virus molecule to be 39 million; on this basis they confidently calculated the tobacco mosaic virus molecule to consist of 108 subunits each of a molecular weight of 360,000 , adding that ". . closer chemical analysis showed that one part [of the decomposition products] contains nucleic acid, whereas another does not". ${ }^{159}$

Another decade went by before proof was obtained of the fact that the infectivity of the tobacco mosaic virus particle resides in its RNA. In early 1956, that proof was delivered almost simultaneously by Gierer and Schramm, by then at the Max Planck Institut für Virusforschung in Tübingen, ${ }^{160}$ and Fraenkel-Conrat, ${ }^{161}$ who had joined Stanley's recently established (1948) department on the Berkeley campus. It followed shortly after another notable success for Stanley's laboratory. In 1955 Schaffer and Schwerdt had there achieved crystallization of the virus of poliomyelitis, the first animal virus to be isolated in crystalline form..$^{162}$

For Schramm, it was the culmination of years of determined attempts to get to the root of a problem with which he had been struggling since the early 1940 s. $^{163}$ Fraenkel-Conrat continued to investigate the mechanisms and interrelations of nucleic acids and coat proteins in plant viruses, which in recent years has led him to a certain amount of collaboration with the French group under Leon Hirth at Strasbourg, ${ }^{164}$ on the question of self-assembly of the protein subunits of alfalfa mosaic virus in the presence of varying amounts of residual RNA. The virus of alfalfa mosaic disease has received much attention lately. The only one of its type known so far, ${ }^{165}$ it boasts at least four and possibly five components, all containing about 18 per cent of single-stranded RNA and all with a diameter of $18 \mathrm{m \mu .}{ }^{166}$

Since 1960, structural studies has been the area within general virology which has seen the greatest impact of studies on tobacco mosaic virus. One would be hard put

${ }^{158}$ G. Schramm, 'Uber die Spaltung des Tabaksmosaikvirus in niedermolekulare Proteine und die Rückbildung hochmolekularen Proteins aus den Spaltstücken', Naturwissenschaften, 1943, 31: 94-96.

${ }^{150}$ Friedrich-Freksa et al., op. cit., note 155 above, p. 206.

${ }^{100}$ A. Gierer and G. Schramm, 'Die Infektiosität der Nucleinsaüre aus Tabakmosaikvirus', $Z$. Naturf., 1956, 11b: 138-142, and 'Infectivity of ribonucleic acid from tobacco mosaic virus', Nature, Lond., 1956, 177: 702-703.

${ }^{161} \mathrm{H}$. Fraenkel-Conrat, 'The role of nucleic acid in the reconstitution of active tobacco mosaic virus', J. Am. chem. Soc., 1956, 78: 882-883.

${ }^{162}$ F. L. Schaffer and C. E. Schwerdt, 'Crystallization of purified MEF-1 poliomyelitis virus particles', Proc. natn. Acad. Sci. U.S.A., 1955, 41: 1020-1023.

${ }^{103}$ See Schramm, op. cit., note 158 above, and also G. Schramm, 'U'ber die Spaltung des Tabaksmosaikvirus und die Wiedervereinigung der Spaltstücke zu hohermolekularen Proteinen I. Die Spaltungsreaktion, II. Versuche über Wiedervereinigung der Spaltstücke', $Z$. Naturf., 1947, 2b: 112$121 ; 249-266$.

${ }^{164}$ G. Lebeurier, H. Fraenkel-Conrat, M. Wurtz and L. Hirth, 'Self-assembly of protein subunits from alfalfa mosaic virus', Virology, 1971, 43: 51-61.

${ }^{105}$ B. H. Harrison, J. T. Finch, A. J. Gibbs, M. Hollings, R. J. Shepherd, V. Valenta, C. Wetter, 'Sixteen groups of plant viruses', ibid., 1971, 45: 356-363, p. 361.

${ }^{168}$ R. Hull, G. J. Hills and R. Markham, 'Studies on alfalfa mosaic virus II. The structure of the virus components', ibid., 1969, 37:416-428. 


\title{
Lise Wilkinson
}

to find a modern textbook on the subject which does not contain the famous diagram of the virion of tobacco mosaic, with its neat array of protein subunits surrounding the helical coil of RNA. Based on a model by Franklin, Klug, Caspar and Holmes, it made its first appearance in a review article on the structure of small viruses published by Klug and Caspar in $1960,{ }^{167}$ and dedicated to the memory of Rosalind Franklin (Fig. 3). Having played her part in the unravelling of the structure of DNA, ${ }^{168}$ Rosalind Franklin had turned her attention to tobacco mosaic virus and in 1955 published in Nature a paper on its structure which summarized the results of previous work and of her own current X-ray diffraction studies. Unhappily, she did not live to conclude the work. Perhaps her contribution, and the extent of international collaboration at this stage, is best summed up by quoting a passage from the obituary written for Nature by Bernal when Rosalind Franklin died in April 1958:

\begin{abstract}
She took up its [tobacco mosaic virus] X-ray study where it had been left in the work of Bernal and Fankuchen fifteen years before, using her improved techniques. Watson had put forward the hypothesis that the virus structure was also a spiral, but one of quite a different order from that which existed in proteins and in deoxyribonucleic acid. Miss Franklin, with the help of much better X-ray photographs than had hitherto been obtained, was able in essence to verify this hypothesis and to correct it in detail. It was at this point that the extremely fruitful co-operation began between Miss Franklin's unit and Fraenkel-Conrat at Berkeley, Caspar at Yale, and Schramm at Tübingen. Using the method of isomorphous replacement, she showed that the virus particle was not solid, as had previously been thought, but actually a hollow tube .... ${ }^{180}$
\end{abstract}

Fraenkel-Conrat is still very much involved in structural studies on plant viruses; $\mathbf{1 7 0}$ Schramm's work, like Rosalind Franklin's, has been cut short by death; Caspar in Boston and Klug at Cambridge are engaging in ever more sophisticated studies of aspects of the physical arrangement of the tobacco mosaic virus particle and of related problems. ${ }^{171}$

When Takahashi and Rawlins in 1932 had first found evidence suggesting that the particles of tobacco mosaic virus were rod-shaped, ${ }^{172}$ it cast doubts on the determinations of particle size which had until then been based on the assumption that the viruses studied, including tobacco mosaic virus, were spherical or near-spherical. The shape was amply confirmed by the studies of Bawden et al. in 1936, and by the electron microscope studies initiated by Kausche, Pfankuch and Ruska in 1939.173 Although many known plant viruses have proved to be rod-shaped like the tobacco

${ }^{167}$ A. Klug and D. L. D. Caspar, 'The structure of small viruses', Adv. Virus. Res., 1960, 7: 225-325, p. 274.

${ }^{168}$ A. Klug, 'Rosalind Franklin and the discovery of the structure of DNA', Nature, Lond., 1968, 219: 808-810.

169 J. D. Bernal, 'Dr. Rosalind E. Franklin', ibid., 1958, 182 : 154.

170 Lebeurier et al., op. cit., note 164 above.

${ }^{171}$ See for example D. L. D. Caspar and K. C. Holmes, 'Structure of Dahlemense strain of tobacco mosaic virus: a periodically deformed helix', J. molec. Biol., 1969, 46: 99-133; and A. C. H. Durham, J. T. Finch and A. Klug, 'States of aggregation of tobacco mosaic virus protein', Nature, Lond., 1971, 229: $37-42$.

172 W. N. Takahashi and T. E. Rawlins, 'Method for determining the shape of colloidal particles; application in study of tobacco mosaic virus', Proc. Soc. exp. Biol. Med., 1932, 30: 155-157.

178 G. A. Kausche, E. Pfankuch and H. Ruska, 'Die Sichtbarmachung von pflanzlichem Virus im Ubermikroskop', Naturwissenschaften, 1939, 27 : 292-299. 


\section{Lessons of the plant viruses-tobacco mosaic virus}

mosaic virus particle, a number of others have been found to be isometric. ${ }^{174}$ But for many years after the identification in 1956 of the nucleic acid of tobacco mosaic virus as RNA, it was tacitly assumed that the infective material of all plant viruses was RNA, until work on the Davis campus of the University of California showed certain surprising properties in a virus causing mosaic disease in cauliflower. The particles of this virus were found to be isometric, with a diameter of $50 \mathrm{~m} \mu$, and its general characteristics brought to mind certain small isometric animal viruses, such as the polyoma and papilloma viruses, rather than the rod-shaped plant viruses. ${ }^{175}$ In 1970 Shepherd, Bruening and Wakeman were finally able to identify its nucleic acid as double-stranded DNA. ${ }^{176}$

Finally, it is worth recording that molecular biology has not yet solved all the problems, and that within the field of plant viruses also, new problems arise as some of the older ones are solved. In the mid-1960s, T. O. Diener, investigating the socalled spindle tuber disease of the potato plant, began uncovering some remarkable facts about a "most unusual viral pathogen". ${ }^{177}$ What Diener first considered to be a double-stranded RNA virus, has later been found to behave as free, infectious RNA which "occurs in the form of several species with molecular weights ranging from $2.5 \times 10^{4}$ to $1.1 \times 10^{5}$ daltons". ${ }^{178}$ Diener's latest results suggest that the structure of the pathogen of potato spindle tuber disease may be similar to that of transfer RNA, where a single strand of RNA is folded in such a way that its character becomes partly double-stranded. Diener has proposed the name "viroid" for this new type of pathogen. ${ }^{179}$ In California, the pathogen of citrus exocortis disease has recently been found to have properties similar to those exhibited by the potato spindle tuber agent. ${ }^{180}$ Sänger in Giessen sees these viroids as another example of the defective plant virus systems he has been investigating. ${ }^{181}$

The most interesting suggestion with regard to future developments is the idea put forward by Diener, that there may be a connexion between the plant viroids and the pathogen responsible for scrapie, a disease attacking the central nervous system of sheep. ${ }^{182}$ In common with kuru and Creutzfeld-Jakob disease in man, scrapie is characterised by the slowness of the course of the infection; the degenerative process

174 Harrison et al., op. cit., note 165 above.

${ }^{175}$ R. J. Shepherd, R. J. Wakeman and R. R. Romanko, 'DNA in cauliflower mosaic virus', Virology, 1968, 36: 150-152.

${ }^{170}$ R. J. Shepherd, G. E. Bruening and R. J. Wakeman, 'Double-stranded DNA from cauliflower mosaic virus', ibid., 1970, 41 : 339-347.

${ }^{177}$ T. O. Diener and W. E. Raymer, 'Potato spindle-tuber virus; a plant virus with properties of a free nucleic acid', Science N.Y., 1967, 158: 378-381.

${ }^{178}$ T. O. Diener, 'Potato spindle tuber 'virus' IV. A replicating, low molecular weight RNA', Virology, 1971, 45: 411-428, p. 411.

170 Ibid., p. 426.

180 J. S. Semancik and L. G. Weathers, 'Exocortis disease: evidence for a new species of "infectious" low molecular weight RNA in plants', Nature, Lond., 1972, 237: 242-244; and J. S. Semancik and L. G. Weathers, 'Exocortis disease: an infectious free-nucleic acid plant virus with unusual properties', Virology, 1972, 47: 456-466.

${ }^{181}$ H. L. Sänger, 'Defective plant viruses', in Molecular genetics, Berlin, Heidelberg, New York, Springer Verlag, 1968, pp. 300-336.

${ }^{182}$ T. O. Diener, 'Is the scrapie agent a viroid?', Nature N.B., Lond., 1972, 235: 218-219; and T. O. Diener, 'Similarities between the scrapie agent and the agent of the potato spindle tuber disease', Ann. clin. Res., 1973, 5: 268-278. 


\section{Lise Wilkinson}

in the nervous system may take months or years to reach its inevitably fatal termination. ${ }^{183}$

If there should prove to be more than a passing similarity between the agents of the slow virus infections in man and the viroids, then perhaps the plant viroids could contribute to our knowledge of the aetiologies of the slow virus infections just as the plant viruses, and above all tobacco mosaic virus, have contributed to our knowledge of the more conventional virus infections since the end of the nineteenth century. But that is very much in the future.

\section{SUMMARY}

The study of plant viruses, and in particular tobacco mosaic virus, has contributed greatly to our knowledge and understanding of the nature of viruses and of the pathogenesis of viral infections in plants, animals and man. The present paper attempts to trace the development of this understanding from the late nineteenth century, when it was first realized that the pathogen of tobacco mosaic disease differed in size and possibly in nature from the more conventional infectious agents then known, to the more recent discoveries concerning the chemistry, morphology and infectivity of tobacco mosaic and other plant viruses which continue to add valuable information to our fund of knowledge of all the pathogenic viruses.

${ }^{183}$ See for example [A. P. Waterson], 'Kuru, Creutzfeldt-Jakob, and scrapie', Lancet, 1974, ii: 1551-1552.

\section{ACKNOWLEDGEMENT}

I am greatly indebted to Professor A. P. Waterson, M.D., F.R.C.P., F.R.C.Path., for many helpful suggestions and discussion of the manuscript. 